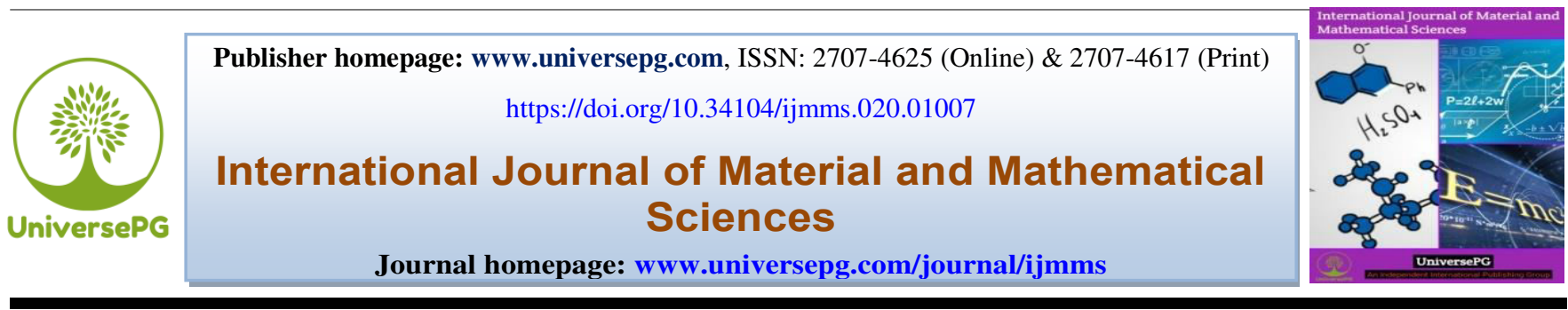

\title{
Low-Cost Jute-Cotton and Glass Fibre Reinforced Textile Composite Sheet
}

\author{
Md. Moslem Uddin ${ }^{1}$, Rezaul Karim ${ }^{2}$, M A Kaysar ${ }^{1}$, Md. Anisur Rahman Dayan ${ }^{1}$, and Kazi Asraful Islam ${ }^{2} *$ \\ ${ }^{1}$ Textile Physics Division, Bangladesh Jute Research Institute, Dhaka-1707, Bangladesh; and ${ }^{2}$ Department of Textile \\ Engineering, Sonargaon University, Dhaka-1212, Bangladesh \\ *Correspondence: kazinooman@gmail.com
}

\begin{abstract}
Composite material is a single structure composed of two or more materials with identifiable interfaces at multi-scales to get properties that are superior to those of its constituents. Composites are designed to get unique mechanical properties and superior performance characteristics that are not possible with any of its component material alone. An experimental work was done at Textile Physics Division of BJRI, Bangladesh, in 2019 for the manufacture of jute, cotton and glass fire reinforced composite corrugated sheet suitable for roofing in poultry and rural housing. For the investigation jute, cotton and glass fibre were used like as reinforcing material and polyester resin were used like as matrix material. This paper reports the findings of an experimental investigation conducted on the engineering properties of jute, cotton and glass fibre reinforced composite corrugated sheet. Different fabric design and volume fractions were used as reinforcement for corrugated sheet to determine the physical, mechanical and thermal properties of the composite. The results of this investigation have showed the feasibility of the use of jute fibre for producing low cost housing materials.
\end{abstract}

Keywords: Jute-Cotton, Glass fibre, Matrix material, Composite material, Jute, Textile, and Fiber.

\section{INTRODUCTION}

The advancement in the fields of material science needs too many new and advance materials. Composites are one of them, each are adopted in various engineering application. Many authors stated many properties of polymer reinforced plastic which make them suitable for variety of application such as aerospace, structures automobile parts and marine structures (Islam et al., 2019). The concept of vegetable fiber reinforcement in the cement based materials was developed in 1970s. In that time vegetable fibres were evaluated as substitutes of manufactured fibres and asbestos fibres (Soroushian and Marihunte, 1992; Portland Cement Association, 1991). Normally, natural vegetable fibres (sisal, cellulose pulp, bamboo, hemp, fique, flax, jute and

UniversePG I www.universepg.com ramie, for example) are used in the regions where these materials are available. According to Swamy (1980), use of composites can represent important contribution to the infrastructure in the developing countries.

It has been demonstrated that fique fibre, which is a commercially available natural fibre in Colombia, is appropriate for low cost housing applications when incorporated into a matrix based on Portland cement, being suitable for making elements of various shapes using simple production processes (Gutierrez and Delvasto, 1993; Alban, 1993; Delvasto et al., 2010). Hybrid composites are newly developed structural materials and are more advanced composites compared to conventional composites (Chamis and Lark, 2014). In principle several fibre reinforcements 
incorporated in a hybrid system, however it is more likely that the combination of only two fibers would be most useful (Gururaja and Hari Rao, 2012). Some of specific benefits of hybrids over conventional composites are:

a) Reduced weight and cost,

b) Balanced stiffness and strength balanced bending membrane mechanical properties, and

c) Improved impact resistance, fatigue resistance and crack resistance properties.

Textile technological developments such as weaving, braiding, and knitting has resulted in the formation of the composites that have superior mechanical properties, since continuous orientation of fibre is not restricted to any point. Researchers, nowadays, have looked into the tensile strength of ramie-cotton hybrid fibre reinforced polyester composites (Junior et al., 2004). They indicate that tensile behavior was dominated by the volume fraction of ramie fibre that is aligned in the test direction. The diameter of the thread and fabric did not play any role in the tensile characteristics. Due to weak cotton/polyester interface cotton fabric was found to have minor reinforcement effect. By Mwaikambo and Bisanda, (1999) similar studies were performed on kapok-cotton fibre reinforced polyester composites. Novolac types of phenol composites reinforced with jute/cotton hybrid woven fabrics were fabricated. Their properties were investigated as a foundation of fibre orientation and roving/fabric characteristics (De Medeiros et al., 2004). Result showed that the composite properties were strongly influenced by test direction of rovings/ fabric characteristics.

The researchers are of the opinion that jute fibre promotes a higher reinforcing effect and cotton fibre avoids catastrophic failure. Therefore, this combination of natural fibres is suitable to produce composites for lightweight structural applications. In housing, roofing is difficult and one of the most important problem. In many industrialized countries, and most developing countries natural materials are used for roofing in rural areas. To the roofing problem, an interesting solution seems to be the thin sheets made of plant fibre concrete. Even if other forms can be produced a corrugated roof sheet is probably one of the most interesting forms. Apart

UniversePG I www.universepg.com from roofing materials plant fibre concrete can be used for production of sun screens, small beams, thin blocks, and other products. In the 1980s, a joint venture project between research institutes in Sweden and Tanzania was carried out with the aim to investigate observed embrittlement of sisal fibre concrete for roofing sheets and find suitable countermeasures. The research found that embrittlement of sisal concrete is due to the fact that the alkaline pore water in the concrete reacts with cellulose components in the fibre so that its load bearing capacity is reduced (Karim et al., 2019).

An interesting measure to improve the resistance of the plant fibre composite against embrittlement is to pre-carbonate the entire composite product. By treating the manufactured composite with carbonic acid or water containing carbonate the carbonation will start the $\mathrm{pH}$-value of the pore water will decrees. If this will be successful the fibre reinforcement must be placed in the other layer of the composite (Gram et $a l .$, 1984). Brazilian research on durability of coir concrete showed that it is possible to increase durability of bio fibres by changing the concrete matrix composition to obtain low alkaline media. The research proved that it is also possible load-bearing structures with bio fibres reinforced composites (John et al., 1980). There are many poetry farms in Bangladesh. In the month of March to May temperature raises up to $400{ }^{0} \mathrm{C}$. This temperature cannot be sustained by the chicken. As a result lots of chicks are died. It is roofing of poultry firms are made by jute-cotton-glass fibre reinforced composite, the temp, decreases with this end in view the study was proposed.

\section{EXPERIMENTAL MATERIAL}

Reinforcing Material - Jute-cotton blended fabric was used as natural reinforcement. Two types of jutecotton blended fabrics (type-1: white color) and (type2: gray color) were used. This fabric was collected from Jute Diversification Proportion Centre (JDPC), Dhaka.

Glass Fabric - Plain weave mat of glass fabric of 156 $\mathrm{mm}$ thickness was used as synthetic reinforced for preparation only one composite sample. This glass 
fibre fabric was collected from Nobabpur Road, Dhaka, Bangladesh.

Liquid Polyester Resin - Liquid Polyester resin was used like a matrix material. This resin was collected from Nasim Plastic Ltd., Dhaka, Bangladesh.

\section{METHODOLOGY}

Composite Corrugated sheet manufacturing process - At first jute-cotton blended and glass fibre fabric were cut into predetermined length and width. Milot paper was also cut according to fabric length and width. Polyester resin was poured on the milot paper. Then jute-cotton blended fabrics were placed on the milot paper and resin was pulled by a roller. Then another piece of jute-cotton blended fabric was placed. By this way all layers are completed. At last one milot paper sheet was placed on top of the composite. Then certain weight is placed over the sample up to certain time.

Table: Properties of jute and jute-cotton blended fabric.

\begin{tabular}{|c|c|c|c|c|c|c|c|c|c|c|}
\hline \multirow[t]{2}{*}{ Fabric Type } & \multirow[t]{2}{*}{ GSM } & \multicolumn{2}{|c|}{$\begin{array}{l}\text { Strength } \\
\text { (lbs) }\end{array}$} & \multicolumn{2}{|c|}{$\begin{array}{l}\text { TPI (twist } \\
\text { per inch) }\end{array}$} & \multicolumn{2}{|c|}{ Count } & \multirow{2}{*}{$\begin{array}{l}\text { Fabric } \\
\text { weave } \\
\text { Design }\end{array}$} & \multicolumn{2}{|c|}{$\begin{array}{l}\text { Elongation } \\
(\%)\end{array}$} \\
\hline & & 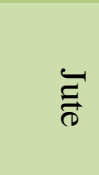 & $\stackrel{0}{\stackrel{0}{\sigma}}$ & 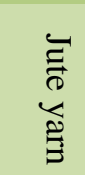 & \气 & 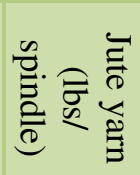 & 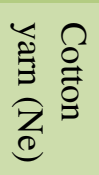 & & 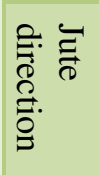 & 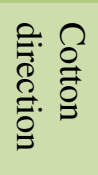 \\
\hline Type-1(all jute) & 400 & 250.0 & - & 4.00 & - & 8.0 & - & Plain 1/1 & 1.50 & - \\
\hline $\begin{array}{l}\text { Type- } 2 \text { Jute cotton blended } \\
\text { fabric (white color) }\end{array}$ & 260 & 139.6 & 65 & 6.12 & 15 & 7.5 & 15 & Plain 1/1 & 1.24 & 2.12 \\
\hline $\begin{array}{l}\text { Type-3 Jute-cotton blended } \\
\text { fabric (Grey color) }\end{array}$ & 300 & 239.0 & 49 & 4.27 & 15 & 8.0 & 15 & Plain 1/1 & 1.54 & 1.88 \\
\hline
\end{tabular}

Table 2: Reinforcing and Matrix Material was applied by the following Ratio.

\begin{tabular}{|l|l|l|}
\hline Ratio & Ratio & Comments/Remarks \\
\hline Fibre : Resin & $1: 1$ & Incomplete Saturation \\
\hline Fibre : Resin & $1: 2$ & Incomplete Saturation \\
\hline Fibre : Resin & $1: 3$ & Partial Saturation \\
\hline Fibre : Resin & $1: 4$ & Complete Saturation \\
\hline
\end{tabular}

Reinforcing and Matrix Material Optimization Polyester Resin was taken 4 times of the Fibre material. 1\% (w/v) Methyl Ethyl Acetone per oxide was taken for hardening of in composite.

\section{RESULT AND DISCUSSION}

Three types of composite were prepared such as;

○ Composite Material-1 (CM1): $100 \%$ jute fabric (one layer)

- Composite Material-2 (CM2): Jute + cotton blended fabric $=($ two layers $)$

○ Composite Material-3 (CM3) : Jute + cotton blended fabric (two layer) + glass fibre fabric (one layer $)=($ three layers $)$

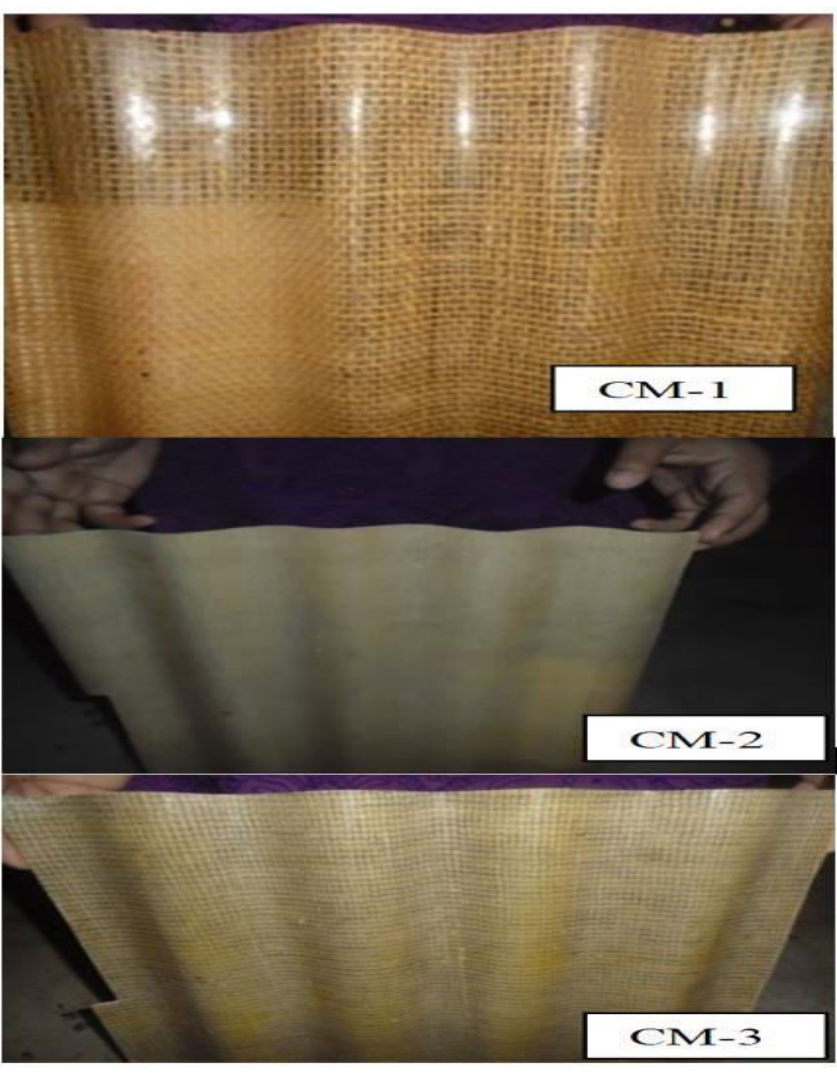

Fig 1: Composite Material-1, 2, and 3. 
Table 3: Tensile Properties of the Hybrid Composite.

\begin{tabular}{|c|c|c|c|}
\hline Sample ID & Thickness (mm) & Ultimate Tensile Strength (MPa) & Elongation (\%) \\
\hline Composite Material-1 & 3.75 & 23.43 & 1.67 \\
\hline Composite Material-2 & 3.75 & 25.76 & 1.17 \\
\hline Composite Material-3 & 3.75 & 29.06 & 2.00 \\
\hline
\end{tabular}

Table 4: Flexural Properties of the Hybrid Composite.

\begin{tabular}{|c|c|c|c|}
\hline Sample ID & Thickness (mm) & Flexural Strength (MPa) & Flexural Modulus (GPa) \\
\hline Composite Material-1 & 3.75 & 38.46 & 2.69 \\
\hline Composite Material-2 & 3.75 & 48.35 & 2.54 \\
\hline Composite Material-3 & 3.75 & 55.62 & 2.20 \\
\hline
\end{tabular}

Table 5: Water Absorption test.

\begin{tabular}{|l|c|c|c|}
\hline Sample ID & Initial weight $(\mathbf{g m})$ & Weight After Water absorption $\mathbf{( g m )}$ & Water absorption \% \\
\hline Composite Material-1 & 10.30 & 10.40 & 0.97 \\
\hline Composite Material-2 & 6.15 & 6.20 & .08 \\
\hline Composite Material-3 & 11.42 & 11.55 & 1.09 \\
\hline
\end{tabular}

Table 6: Thickness Change test.

\begin{tabular}{|c|c|c|c|}
\hline Sample ID & $\begin{array}{c}\text { Initial thickness } \\
(\mathbf{m m})\end{array}$ & $\begin{array}{c}\text { Thickness after water } \\
\text { absorption } \mathbf{( m m})\end{array}$ & $\begin{array}{c}\text { Change in thickness due } \\
\text { to water absorption \% }\end{array}$ \\
\hline Composite Material-1 & 3.75 & 4.00 & 6.67 \\
\hline Composite Material-2 & 3.75 & 3.88 & 4.49 \\
\hline Composite Material-3 & 3.75 & 3.95 & 5.33 \\
\hline
\end{tabular}

\section{Graphical Representation}

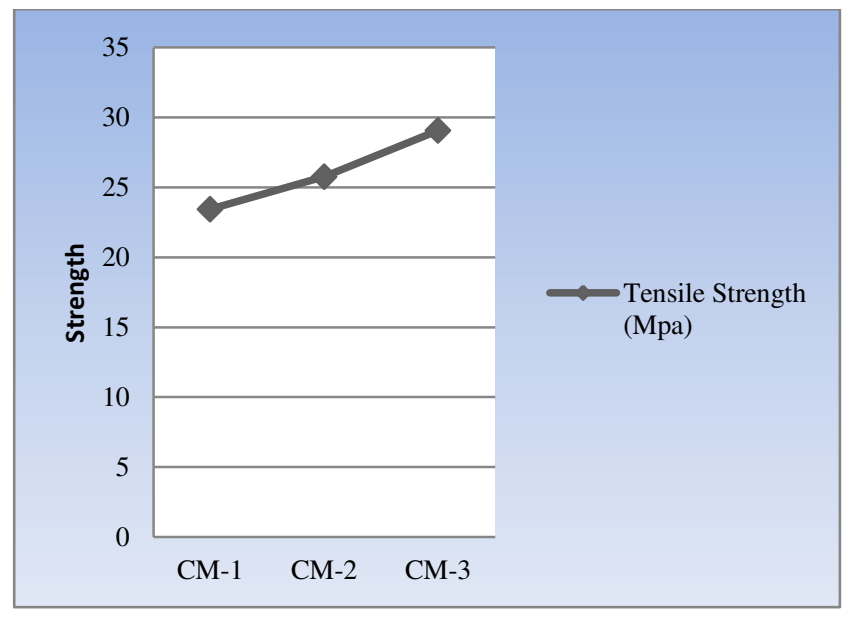

Fig 2: Variation of Tensile Strength.

UniversePG I www.universepg.com

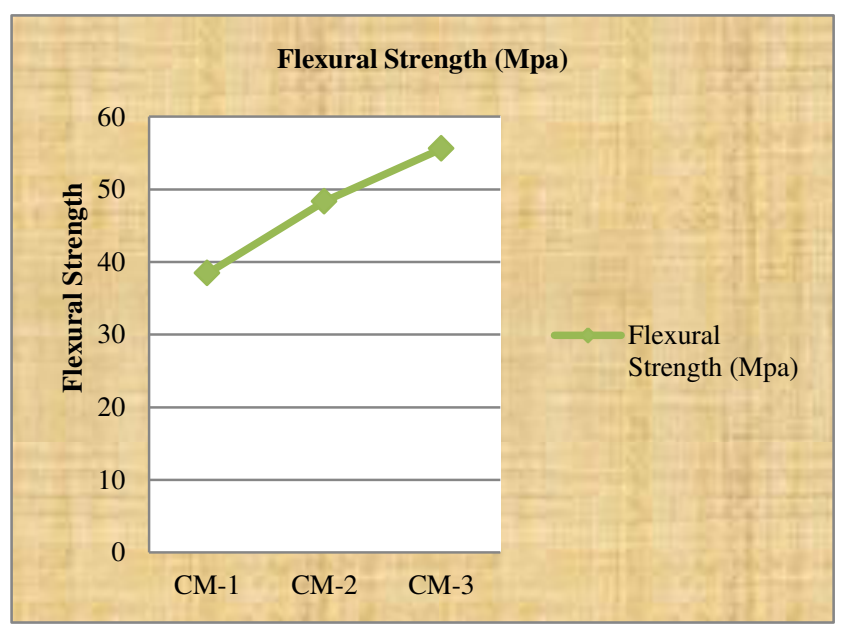

Fig 3: Change of Flectural Strength. 


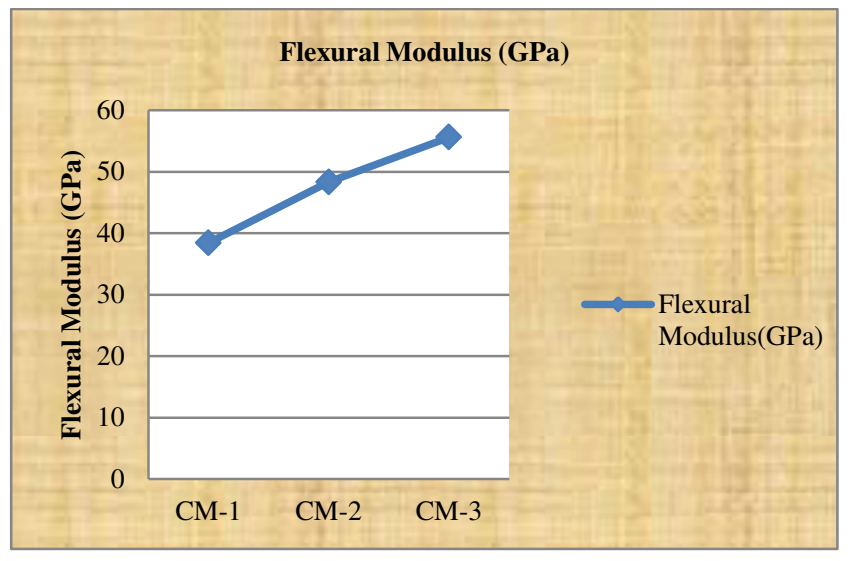

Fig 4: Variation of Flexural Modulus.

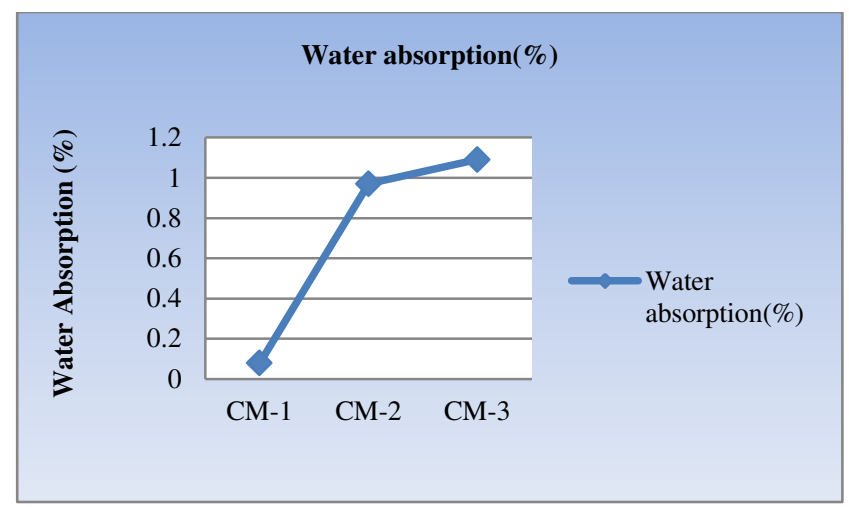

Fig 5: Percent of Water Absorption.

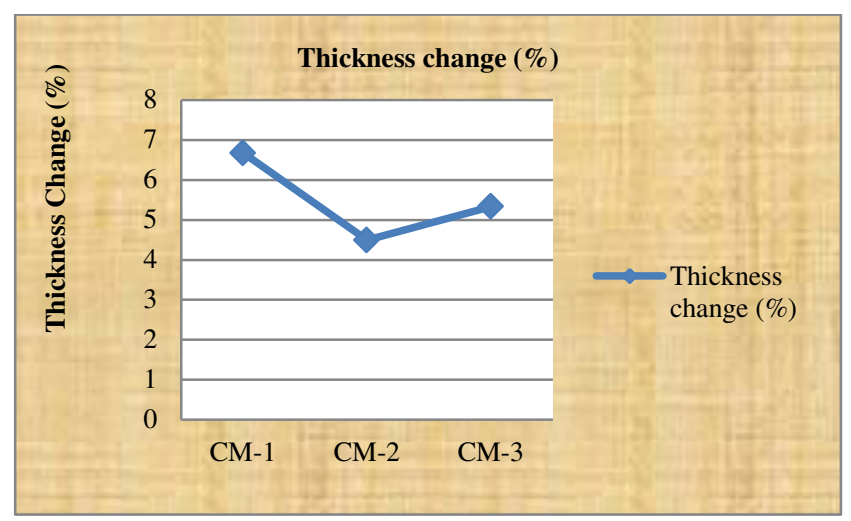

Fig 6: Percent of Thickness Change.

Mechanical Test Result - Experimental results of tensile and flexural strengths and flexural modulus of three types of composites with different weight fractions of reinforcement are presented in table 3 and 4. Graphical representation of tensile and flexural strength and flexural modulus are given in Fig 2, Fig 3, and Fig 4 respectively. The results show that the addition of natural and glass fibre increased the tensile and flexural strength of the composite.

UniversePG I www.universepg.com

\section{Thickness Change test}

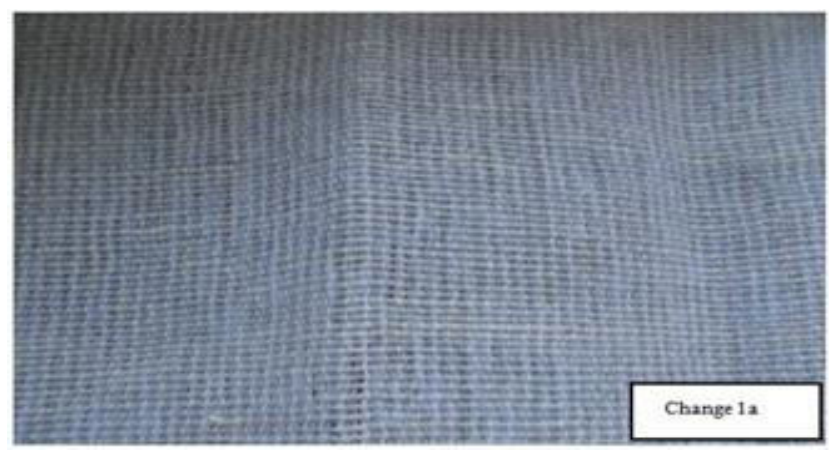

Fig 7: Change 1a.

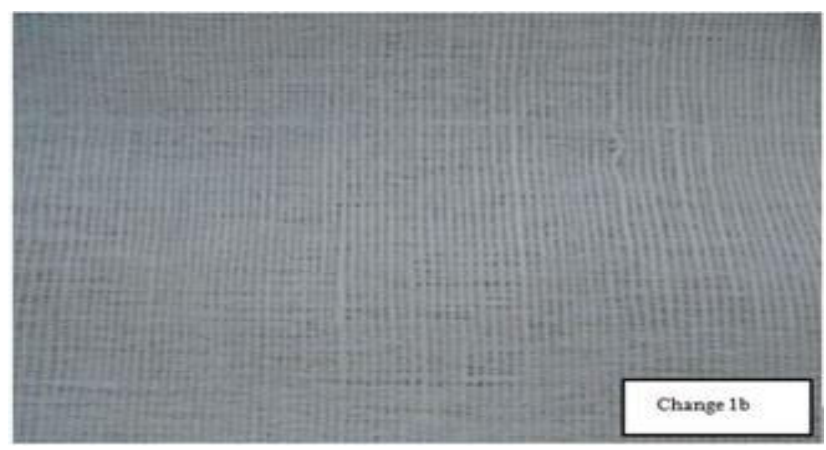

Fig 8: Change 1b.

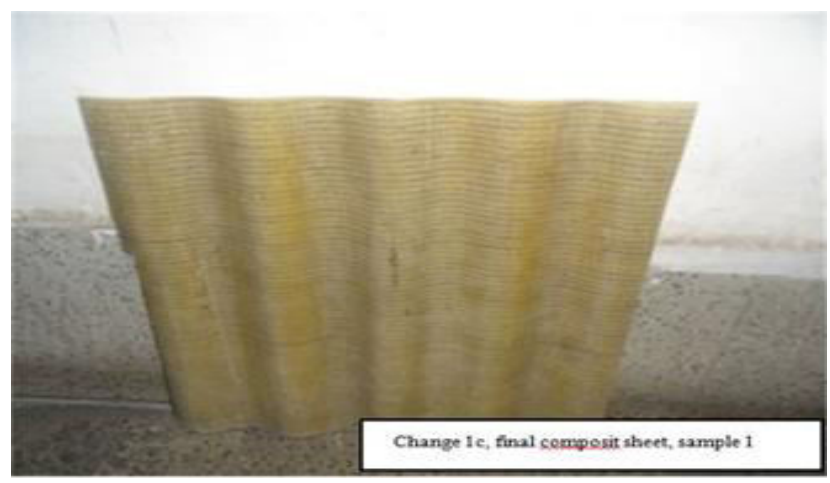

Fig 9: Change 1c.

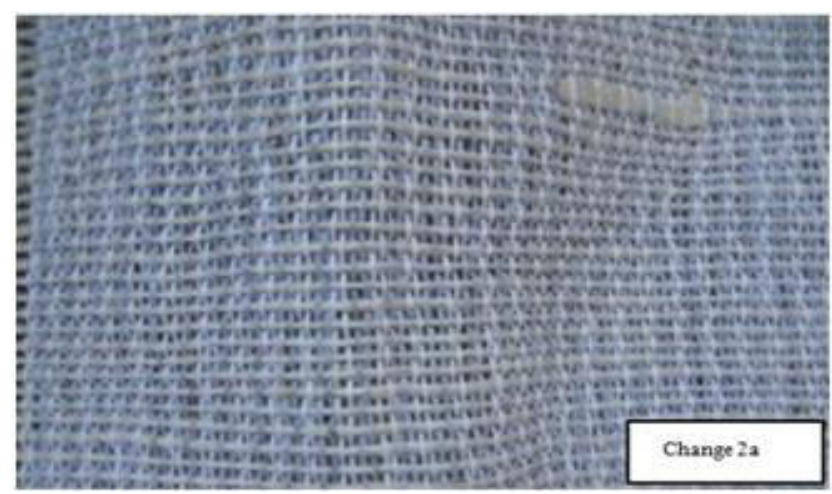

Fig 10: Change of sample 2. 


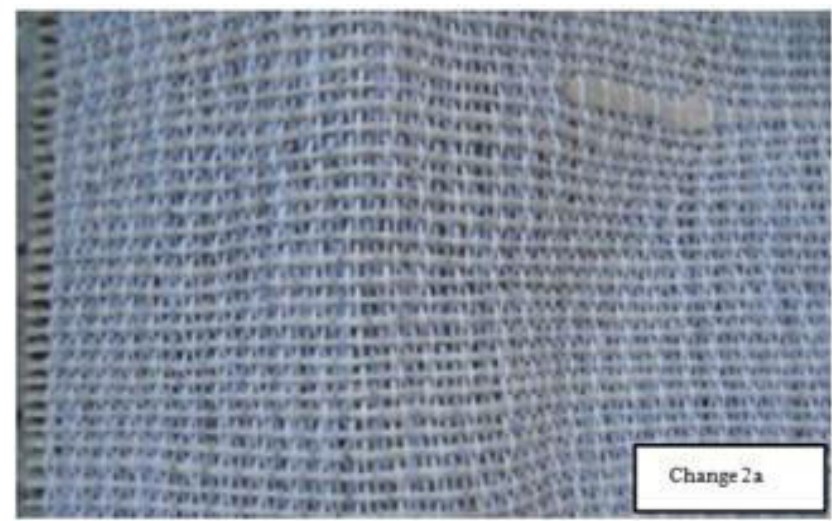

Fig 11: Change 2a.

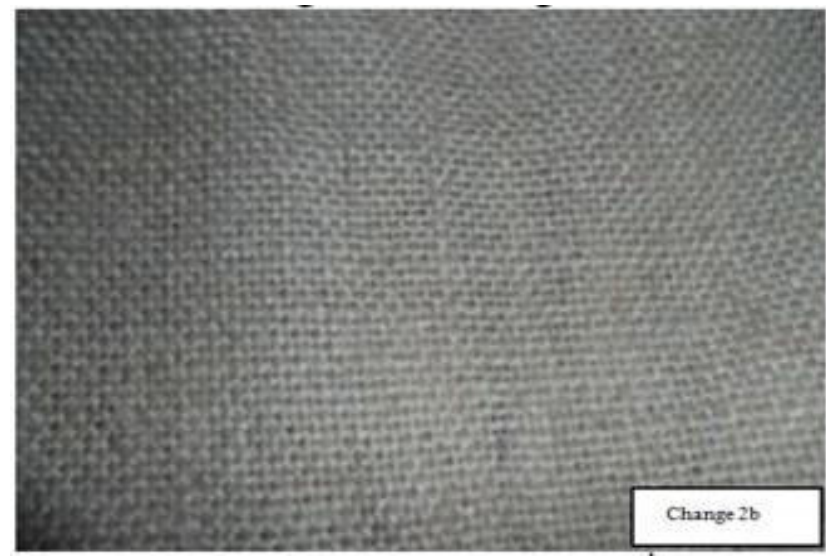

Fig 12: Change $2 b$.

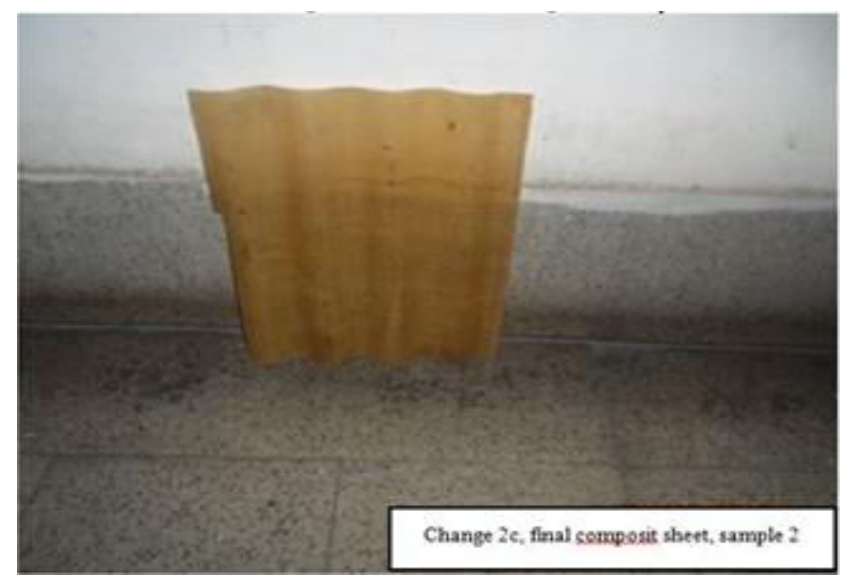

Fig 13: Change 2c.

Experimental results of thickness change after water absorption for the three types of composites are presented in Table 6, and its graphical representation given in Fig 6. Step by step changes are given Fig 7 to Fig 13. For the satisfaction we performed the experiment on thick (2a, 2b and 2c) and thin (1a, 1b and 1c) composite sheets, we produced.

UniversePG I www.universepg.com
Water absorption test - The percentage of water absorbed by the composites was determined by finding the weight difference between samples, immersed in water and dry samples using

$$
\mathrm{W}(\%)=(\mathrm{Wi}-\mathrm{Wf}) / \mathrm{Wi}
$$

Where,

$\mathrm{W}$ is the percentage of water absorption,

Wi is initial weight of water, and

Wf the weight of wet sample

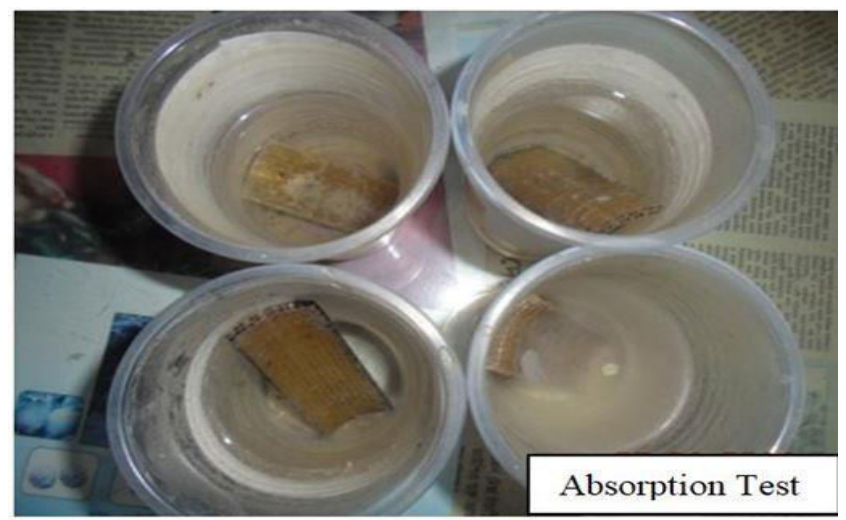

Fig 14: Water absorption test.

Fig 14 shows the water absorption part. Observation of Table 5 and Fig 5 revealed that when jute and cotton fibre were hybridized with glass fibre, the water absorption was reduced. Finally, it is concluded that produced jute-cotton and glass fibre reinforced textile composite sheet is cost-effective, eco-friendly, easy to produce, and long lasting. Therefore, more research and investment is necessary for further development and mass production of this cost-effective composite material.

\section{ACKNOWLEDGEMENT}

We are gratefully acknowledged to BJRI and Nasim Plastic Ltd., Dhaka, Bangladesh.

\section{CONFLICTS OF INTEREST}

The authors declared no prospective conflicts of the interest with respect to the research work.

\section{REFERENCES}

1. Alban F., (1993). Cabuya fiber mortar for corrugated tiles and flat sheets, ceramic matrix composites and other systems, In: Proceeding 
of the ninth international conference on composite materials (ICCM/9), University of Zaragoza, 830-3.

2. Chamis C.C, and Lark R. F, (2014). "Hybrid Composites-State-Of-art review: Analysia. Design, Application and Fabrication," Lewis Research Center.

3. Delvasto S, Toro EF, Perdomo F, and Mejia de Gutierrez R, (2010). An appropriate vacuum technology for manufacture of corrugated fique fibre reinforced cementations sheets, Construct Build Mater, 24(2), 187-92. https://doi.org/10.1016/j.conbuildmat.2009.01. $\underline{010}$

4. De Medeiros E.S, Agnelli J.A.M., De Carvalho L.H., and Mattoso L.H.C, (2004). Polym. Com. Test, 2611

5. Gram H-E, Persson H, and Skarendahi A, (1984). Natural Fibre Concrete- Report from a SAREC-financed Research and Development Project, Saree Report R2: Stockolm.

6. Gururaja MN and Hari Rao AN, (2012). A review on Recent Application and Future Prospectus of Hybrid Composites, International of Soft Computing and Engineering (IJSCE) ISSN: 2231-2307, Vol 1, issue 6.

7. Gutierrez R, and Delvasto S, (1993). Cabuya in cement composites ceramic matrix composites and other systems, In: Proceedings of the ninth international conference on composite material (ICCM/9), University of Zaragoza, 834-41.

8. Islam KA, Deeba F, and Hassan MKA. (2019). Dust Ion Acoustic Solitary Waves in Multi-Ion Dusty Plasma System with
Adiabatic Thermal Change, Aust. J. Eng. Innov. Technol., 1(5), 1-5. https://doi.org/10.34104/ajeit.019.0105

9. John, V., Agopyan M, and Derolle V. A., (1990). Durability of Blast Furnance-SlagBased Cement Mortar Reinforced with Coir Fibres, Proceedings of the Second International Symposium sponsored by RILEM and CIB, Salvador, Brazil, 17-21.

10. Junior C.Z.P, Carvalho L.H, Fonseca V.M., Monteiro S.N, and Almeida J.R.M, (2004). Polym. Test. 131

11. Karim R, Razzak A, Mahabubuzzaman AKM, and Shahid A. (2019). Comparison of the Quality Parameter between Cotton and Melange process, Aust. J. Eng. Innov. Technol., 1(6), 21-30.

https://doi.org/10.3414/ajeit.019.21030

12. Mwaikamb L.Y, and Bisanda E.T.N., (1999). Polym. Test, 18-181

13. Portland cements Association, (1991). Fiber reinforced concreta, PCA.

14. Soroushian P., and Marihunte S. (1992). High performance cellulose fibre reinforced cerment composites, In: Proceeding of the international workshop high performance fiber reinforced cement composites, PILEM, E\&FN SPON.

15. Swamy RN, (1980). Influence of slow crack growth on the fracture resistance of fibre cement composites. Int J. Cem Compos, 2(1), 43-53.

https://pascal-francis.inist.fr/vibad/index.php? action $=$ getRecordDetail\&idt=PASCALBTP80 $\underline{80332263}$ 